\title{
Characterization of antimicrobial substance from Lactobacillus salivarius KL-D4 and its application as biopreservative for creamy filling
}

Phatthanaphong Therdtatha ${ }^{1,2}$, Chanabhorn Tandumrongpong ${ }^{1}$, Komkhae Pilasombut ${ }^{3}$, Hiromi Matsusaki ${ }^{4}$, Suttipun Keawsompong ${ }^{1,2}$ and Sunee Nitisinprasert ${ }^{1,2^{*}}$

*Correspondence: fagisnn@ ku.ac.th

${ }^{1}$ Specialized Research Unit, Probiotics and Prebiotics for Health, Department of Biotechnology, Faculty of Agro-Industry, Kasetsart University, Bangkok 10900, Thailand

Full list of author information is available at the end of the article

\begin{abstract}
Lactobacillus salivarius KL-D4 isolated from duck intestine produced bacteriocin which was stable at high temperature and a wide $\mathrm{pH}$ range of $3-10$. Its cell free supernatant at pH 5.5 exhibited wide inhibitory spectrum against both $\mathrm{G}+$ and $\mathrm{G}-$ bacteria. The highest bacteriocin production was obtained in MRS broth supplemented with $0.5 \%$ $(\mathrm{w} / \mathrm{v}) \mathrm{CaCO}_{3}$ at $6 \mathrm{~h}$ by gentle shaking. PCR walking using specific primers at the conserved region of class-II bacteriocin resulted in 4 known genes of $k / d 1, k l d 2, k l d 3$ and kld4 with $100 \%$ similarity to genes encoding for salivaricin $\alpha, \beta$, induction peptide and histidine protein kinase of $L b$. salivarius $G J-24$ which did not previously report for bacteriocin characterization, while showing $94,93,59$ and $62 \%$ to other salivaricin gene cluster, respectively. The high activities of $25,600 \mathrm{AU} / \mathrm{ml}$ indicated a strong induction peptide expressed by $k / d 3$ which has low similarity to previous inducer reported. Based on operon analysis, only $k l d 1, k l d 3$ and $k l d 4$ could be expressed and subsequently elucidated that only salivaricin a like bacteriocin was produced and secreted out of the cells. Using protein purification, only a single peptide band obtained showed that this strain produced one bacteriocin which could be salivaricin a namely salivaricin KLD showing about $4.3 \mathrm{kDa}$ on SDS-PAGE. Partial purification by $20 \%$ ammonium sulfate precipitation of the product was tested on the artificial contamination of creamy filling by Bacillus cereus, Enterococcus faecalis, Pseudomonas stutzeri, Staphylococcus sp. and Stenotrophomonas sp. resulting the growth inhibitory efficiency of 4.45-66.9, 11.5-100, 100, 0-28.1 and 5-100\% respectively. Therefore, salivaricin KLD can be a tentative biopreservative for food industry in the future.
\end{abstract}

Keywords: Lactobacillus salivarius, Salivaricin, Bakery products, Creamy filling, Biopreservative

\section{Background}

Bakery products usually contain basic elements of milk, butter, starch, eggs and sugar that provide the nutrient sources for the good growth of microbial contaminants (Pyler 1988). However, these food products are generally considered to be microbiologically safe due to the high temperature of up to $170{ }^{\circ} \mathrm{C}$ used in the baking process. Usually, 
baked products do not pose a health risk unless they have cream or custard filling containing egg or a dairy product (Stewart et al. 2003). This filling is the most likely source of a serious food safety hazard due to post-baking microbial contamination. Another risk may arise from climatic conditions facilitating microbial growth, especially in a tropical country like Thailand. Several antimicrobial substances, such as acetic acid, propionic acid, sorbic acid and their salts have been used as food preservatives to extend a product's shelf life (Smith et al. 2004). However, their inhibition efficiencies at the neutral $\mathrm{pH}$ of bakery products with creamy filling have been reported as low which corresponded to previous studies proposed that chemical preservatives are only effective in bakery products at $\mathrm{pH}<6.5$ (Guynot et al. 2005; Rosenquist and Hansen 1998). Schmidt et al. (1969) reported that both potassium sorbate and sodium benzoate at a concentration of $1000 \mathrm{ppm}$ could inhibit the growth of Staphylococcus aureus in synthetic cream pies at 22 and $37^{\circ} \mathrm{C}$ and at $\mathrm{pH} 4.5-5.0$ but not at a higher $\mathrm{pH}$ of 5.2. In addition, it was found that calcium propionate shows no inhibition against rope-producing spores containing B. subtilis, B. licheniformis and B. pumilus in white bread (Thompson et al. 1998).

Recently, biopreservatives produced by lactic acid bacteria (LAB) have been of interest due to consumer concerns regarding chemical additives in food products. Bacteriocin, one of effective biopreservative compounds, is a ribosomally synthesized peptide that has been investigated and widely applied for food preservative in the bakery industry (Chen and Hoover 2003; Galvez et al. 2007). Enterocin AS-48, which is produced by E. faecalis A-4832 , is able to partially reduce the populations of spoilage and potential endospore-forming bacilli in wheat dough stored at $22{ }^{\circ} \mathrm{C}$ at a concentration of $14 \mathrm{AU} / \mathrm{g}$ (Viedma et al. 2011). Lactobacillus salivarius, one alternative from bacteriocin producing strains is potential to be the biopreservative for bakery products. This species is usually reported as a probiotic candidate frequently isolated from human, porcine, and avian gastrointestinal tracts (Dobson et al. 2012). It often produces bacteriocin belonging to class II, which typically exhibits antibacterial activity against spoilage bacteria, as well as food-borne pathogens (Messaoudi et al. 2013). Salivaricin ABP-118, which is produced by Lb. salivarius UCC118, demonstrates a broad-spectrum of antibacterial activity, including the Gram-positive bacteria of Listeria, Staphylococcus, Enterococcus and Bacillus species (Dunne et al. 1999). Salivaricin FK22, which is produced by Lb. salivarius K7, displays inhibitory activity against Grampositive bacteria (Pilasombut et al. 2006). It is also reported that salivaricin CRL1328, which is produced by Lb. salivarius CRL1328, shows bacteriocin activity against potential bacteria causing food-poisoning such as E. faecalis and E. faecium (Ocaña et al. 1999).

In our laboratory, Lb. salivarius KL-D4 isolated from duck intestine was preliminarily investigated and found that it was able to produce antimicrobial substance (AMS) against potential foodborne pathogen. Therefore, given such potential efficiency, this study aimed to characterize the AMS produced by the strain KL-D4 and further investigate its application as a biopreservative in creamy filling.

\section{Methods}

Bacterial strains and culture conditions

Lactobacillus salivarius KL-D4 was used as an AMS producer strain and cultivated in MRS broth (Difco, USA) at $37{ }^{\circ} \mathrm{C}$. All target bacterial strains and their growth conditions used in this study were listed in Table 1 . All strains were maintained at $-80{ }^{\circ} \mathrm{C}$ 
Table 1 List of target bacterial strains and their cultivation conditions

\begin{tabular}{|c|c|c|}
\hline Indicator strain & Media & Temperature $\left({ }^{\circ} \mathrm{C}\right)$ \\
\hline \multicolumn{3}{|l|}{ Lactic acid bacteria } \\
\hline Lactococcus lactis subsp. cremoris TISTR1344 & MRS & 30 \\
\hline Lactobacillus plantarum ATCC14917 & MRS & 30 \\
\hline Lactobacillus sakei subsp. sakei JCM1157 ${ }^{\top}$ & MRS & 30 \\
\hline Lactobacillus sakei TISTR890 & MRS & 30 \\
\hline Leuconostoc mesenteroides subsp. mesenteroides JCM6124 & MRS & 30 \\
\hline Leuconostoc mesenteroides subsp. mesenteroides TISTR942 & MRS & 30 \\
\hline Enterococcus fecalis KUB-E5 & NB & 37 \\
\hline Enterococcus fecalis KUB-E7 & NB & 37 \\
\hline \multicolumn{3}{|l|}{ Other Gram-positive bacteria } \\
\hline Bacillus cereus JCM2152 & NB & 37 \\
\hline Bacillus coagulans JCM2257 & TSBYE & 37 \\
\hline Bacillus coagulans TISTR1447 & TSBYE & 37 \\
\hline Brochotrix campeatris NBRC 11547 & TSBYE & 25 \\
\hline Listeria innocua ATCC33090 & TSBYE & 37 \\
\hline Staphylococcus epidermidis KUB-E6 & NB & 37 \\
\hline Staphylococcus hominis KUB-E8 & NB & 37 \\
\hline Streptococcus sp. TISTR1030 & NB & 30 \\
\hline \multicolumn{3}{|l|}{ Gram-negative bacteria } \\
\hline Aeromonas hydrophila TISTR1321 & NB & 30 \\
\hline Escherichia coli O157:H7 & NB & 37 \\
\hline Pseudomonas fluorescens JCM5963 & TSBYE & 25 \\
\hline Pseudomonas fluorescens TISTR358 & TSBYE & 25 \\
\hline Pseudomonas stutzeri KUB-E1 & NB & 37 \\
\hline Salmonella enterica serova Enteritidis DMST17368 & NB & 37 \\
\hline Stenotrophomonas sp. KUB-E2 & NB & 37 \\
\hline
\end{tabular}

ATCC American Type Culture Collection, Rockville, Md; DMST Department of Medical Science Thailand, Thailand; JCM Japanese Culture of Microorganism, Wako, Japan; NBRC National Institute of Technology and Evaluation (NITE) Biological Resource Center; TISTR Thailand Institute of Scientific and Technological Research; KUB Department of Biotechnology, Kasetsart University, Thailand

in appropriate media containing $20 \%$ (v/v) glycerol (Univar, Australia). Escherichia coli DH5 $\alpha$, which was used as a host for cloning, was grown in Luria-Bertani broth (Sambrook et al. 2001) supplemented with $100 \mu \mathrm{g} / \mathrm{ml}$ of amplicillin (Amresco, USA) at $37{ }^{\circ} \mathrm{C}$ with vigorous agitation for 16-18 h.

\section{Determination of enzyme sensitivity}

The sensitivity of the bacteriocin to proteolytic enzymes and other enzymes was performed using a reaction containing $1 \mathrm{ml}$ of cell free supernatant (CFS) and $1 \mathrm{mg} / \mathrm{ml}$ of each enzyme for $2 \mathrm{~h}$ under the following suitable conditions: trypsin and $\alpha$-chymotrypsin (Sigma-Aldrich, USA) at $25^{\circ} \mathrm{C}$ and $\mathrm{pH} 8.5 ; \alpha$-amylase (Sigma-Aldrich, USA) at $25^{\circ} \mathrm{C}$ and pH 7.0; proteinase K (Sigma-Aldrich, USA) at $37^{\circ} \mathrm{C}$ and pH 8.0; actinase E (Kaken Pharmaceutical, Japan) and lipase (Sigma-Aldrich, USA) at $37^{\circ} \mathrm{C}$ and $\mathrm{pH} 7.0$; pepsin at $37^{\circ} \mathrm{C}$ and pH 3.0 (Nacalai Tesque, Japan). After incubation, all reaction mixtures were heated at $100{ }^{\circ} \mathrm{C}$ for $5 \mathrm{~min}$ and the residual inhibitory activity was determined against $\mathrm{Lb}$. sakei subsp. sakei JCM $1157^{\mathrm{T}}$ using the spot-on-lawn method. 


\section{Determination of growth and bacteriocin production}

Bacteriocin productivity and growth determination were adapted from Flynn et al. (2002) and Yamamoto et al. (2003). One percent innoculant of KL-D4 strain was grown in $100 \mathrm{ml}$ of MRS broth under four different conditions: static, static supplemented with $0.5 \%(\mathrm{w} / \mathrm{v})$ of $\mathrm{CaCO}_{3}$ (Scharlau, European Union), shaking at $120 \mathrm{rpm}$ and shaking at $120 \mathrm{rpm}$ supplemented with $0.5 \%(\mathrm{w} / \mathrm{v})$ of $\mathrm{CaCO}_{3}$. All broth cultures were then incubated at $37{ }^{\circ} \mathrm{C}$ for $24 \mathrm{~h}$ to determine their effects on cell growth and bacteriocin production. Each sample was withdrawn from its broth culture every $3 \mathrm{~h}$ to determine cell concentration, $\mathrm{pH}$, and inhibitory activity. The viable cells were monitored in two replications by a standard plate count technique (Wehr and Frank 2004). The specific growth rate $(\mu)$ at the exponential phase was calculated equation below:

$$
\mu=\frac{\left(\ln x_{t 2}-\ln x_{t 1}\right)}{\left(t_{2}-t_{1}\right)}
$$

where $x_{t 1}$ and $x_{t 2}$ are the viable cell concentration measured within the exponential phase of growth at times $t_{1}$ and $t_{2}$, respectively.

For further determination of inhibitory activity, the CFS was prepared by heating at $70{ }^{\circ} \mathrm{C}$ for 30 min and tested against $L b$. Sakei subsp. sakei JCM $1157^{\mathrm{T}}$ by the spot-on-lawn method.

\section{Determination of $\mathrm{pH}$ and heat stability}

Samples of the CFS of $16 \mathrm{~h}$ culture solution were adjusted to $\mathrm{pH}$ values of 3.0, 4.0, 5.0, 5.5, 6.0, 7.0, 8.0, 9.0 and 10.0 and incubated at $37{ }^{\circ} \mathrm{C}$ for $2 \mathrm{~h}$. All samples were then adjusted to $\mathrm{pH} 5.5$ and determined for their residual activities. To determine heat stability, CFS samples were adjusted to $\mathrm{pH} 5.5$ and heated at $100{ }^{\circ} \mathrm{C}$ for 5 and $30 \mathrm{~min}$ and at $121{ }^{\circ} \mathrm{C}$ for $15 \mathrm{~min}$. The remaining bacteriocin activities were determined against $L b$. sakei subsp. sakei JCM $1157^{\mathrm{T}}$ by the spot-on-lawn method.

\section{Determination of inhibitory activity}

An inhibitory activity was determined using the spot-on-lawn method according to the modified method of Ennahar et al. (1999). The $1.0 \%$ (w/v) soft agar medium, containing the target strain of approximately $10^{7} \mathrm{CFU} / \mathrm{ml}$ was overlaid on the same medium containing $1.5 \%(\mathrm{w} / \mathrm{v})$ agar. CFS was adjusted to $\mathrm{pH} 5.5$ with $5 \mathrm{~N} \mathrm{NaOH}$ solution (Merck, Germany) and heated at $70{ }^{\circ} \mathrm{C}$ for $30 \mathrm{~min}$. Ten microliters of the sample was spotted onto the overlaid surface and the plate was incubated at an appropriate temperature for each target strain for $18 \mathrm{~h}$. The activity was defined as the reciprocal of the last serial dilution giving a zone of inhibition and expressed as activity units (AU) per milliliter.

\section{Identification of bacteriocin by polymerase chain reaction (PCR)}

Identification of genes related to the production and regulation of bacteriocin from $L b$. salivarius KL-D4 strain was performed using the PCR walking technique detailed below. All of the primers used in the experiment were shown in Table 2. 
Table 2 List of primers and nucleotide sequences

\begin{tabular}{|c|c|c|}
\hline Primer set & Sequence $5^{\prime}-3^{\prime}$ & Purpose \\
\hline SalAa-f1 & 5'-ATGAAGGAATTTACAGTATTGACAGAATGT-3' & To amplify kld 1 \\
\hline SalAa-r1 & 5'-TTATAAACAAGTAAGCGCTCCGCCTACCAT-3' & \\
\hline D4-f1 & 5'-GCTGGTATTGTAGGCGGAGCAAACTTAGGA-3' & To amplify kld2,3,4 \\
\hline Oligo105 & $5^{\prime}$-CYTCDATNGCRTTRTC-3'* & \\
\hline D4-f1 & 5'-GCTGGTATTGTAGGCGGAGCAAACTTAGGA-3' & To amplify kld5 \\
\hline D4-r1 & 5'-CTACACAATTAGGATAACGTTTCCCACCGT-3 & \\
\hline D4-f2 & 5'-GATTAAGACATTCAAATCAAGATATTTGTA-3' & To confirm kld locus \\
\hline D4-r2 & 5'-ATGTAACGACTATAAATACAATATTTTGTT-3' & \\
\hline T7 promoter & 5'-TAATACGACTCACTATAGGG-3' & Colony PCR for pT7Blue-T vector \\
\hline U-19mer & 5'-GTTTTCCCAGTCACGACGT-3' & \\
\hline M13RV & $5^{\prime}-$ CAGGAAACAGCTATGAC-3' & Colony PCR for pMD20-T vector \\
\hline M13M4 & 5'-GTTTTCCCAGTCACGAC-3' & \\
\hline
\end{tabular}

\section{Polymerase chain reaction}

Total DNA of Lb. salivarius KL-D4 was extracted following Sato et al. (2000) and used as a template for the PCR amplification. Firstly, PCR was performed using the forward and reverse primers SalA $\alpha-\mathrm{f} 1$ and $S a l A \alpha-r 1$, respectively, based on the nucleotide sequence of salivacin K21 (Matsusaki et al. 2006). About 50-200 ng of DNA template was amplified with $0.5 \mu \mathrm{M}$ of each primer in $50 \mu \mathrm{l}$ of premix solution (Takara Bio Inc, Japan), containing 1.25 units of Ex Taq HS DNA polymerase, $1 \times$ Ex Taq buffer $\left(\mathrm{Mg}^{2+}\right.$ plus), and $0.2 \mathrm{mM}$ of dNTPs. The PCR conditions were: denaturation at $94{ }^{\circ} \mathrm{C}$ for $3 \mathrm{~min}$, followed by 30 cycles including denaturation at $94{ }^{\circ} \mathrm{C}$ for $1 \mathrm{~min}$, annealing at $45^{\circ} \mathrm{C}$ for $1 \mathrm{~min}$ and extension at $72{ }^{\circ} \mathrm{C}$ for $2 \mathrm{~min}$. The second PCR followed was performed using an internal sense primer D4-f1 located at the internal sequence of the first PCR product and Oligo105 related to the consensus sequence of histidine protein kinase (Losteinkit et al. 2001). The reaction of the PCR mixtures (50 $\mu \mathrm{l}$ ) consisted of about 50-200 ng of DNA template, $0.5 \mu \mathrm{M}$ of D4-f1 primer, $1.5 \mu \mathrm{M}$ of Oligo105 primer, 1.25 U of Ex Taq HS DNA polymerase, $1 \times$ Ex Taq buffer $\left(\mathrm{Mg}^{2+}\right.$ plus) and $0.2 \mathrm{mM}$ of dNTPs. The PCR conditions were: denaturation at $94{ }^{\circ} \mathrm{C}$ for $3 \mathrm{~min}$, followed by 30 cycles included denaturation at $94{ }^{\circ} \mathrm{C}$ for $1 \mathrm{~min}$, annealing at $53{ }^{\circ} \mathrm{C}$ for $1 \mathrm{~min}$ and extension at $72{ }^{\circ} \mathrm{C}$ for $3 \mathrm{~min}$. PCR product obtained was analysed by agarose gel electrophoresis and further submitted for cloning and nucleotide sequence analysis.

\section{Inverse $P C R$}

An inverse PCR technique was performed using the DNA template of restriction enzyme digested chromosomal DNA and primers of D4-f1 and the internal antisense primer D4-r1 located on the internal sequence of the first PCR product. The genomic DNA was randomly cut by restriction enzymes, including ApaI, SalI, BanIII, HindIII, EcoRI, XbaI, XhoI, SacI and SacII (Takara Bio Inc, Japan). Each enzymatic treatment was performed in $400 \mu \mathrm{l}$ of premix solution, containing $50 \mathrm{ng}$ of genomic DNA, 10X buffer of each enzyme and 1 unit of the enzyme. All treatments were incubated at $37^{\circ} \mathrm{C}$ for $24 \mathrm{~h}$. Subsequently, the digested DNA was purified using a phenol-chloroform treatment and 
precipitated using cold ethanol. Self ligation of the digested DNA obtained was performed in $5 \mu \mathrm{l}$ of Ligation high Ver.2 (Toyobo, Japan) at $16^{\circ} \mathrm{C}$ for $2 \mathrm{~h}$. The ligated DNA solution was purified using ethanol precipitation, dried using a Mini Vacuum-Centrifugal Evaporator (Tomy, Japan) and dissolved in $100 \mu \mathrm{l}$ of TE buffer. To perform the inverse PCR reaction, $10 \mathrm{ng}$ of each ligation product was amplified with $10 \mu \mathrm{M}$ of each primer in $50 \mu \mathrm{l}$ of premix solution (Takara Bio Inc, Japan) containing, $10 \mu \mathrm{M}$ of D4-f1 primer, $10 \mu \mathrm{M}$ of D4-r1 primer, 1.25 units of PrimeSTAR HS DNA polymerase (TaKaRa, Japan), $5 \times$ PrimeSTAR buffer ( $\mathrm{Mg}^{2+}$ plus) and $2.5 \mathrm{mM}$ of dNTPs. The amplification program was $94{ }^{\circ} \mathrm{C}$ for $3 \mathrm{~min}, 30$ cycles of $98^{\circ} \mathrm{C}$ for $10 \mathrm{~s}, 55^{\circ} \mathrm{C}$ for $5 \mathrm{~s}, 72{ }^{\circ} \mathrm{C}$ for $10 \mathrm{~min}$ with a final extension at $72{ }^{\circ} \mathrm{C}$ for $20 \mathrm{~min}$. PCR product obtained was analysed by agarose gel electrophoresis and further submitted for cloning and nucleotide sequence analysis.

\section{Analysis of gene cluster from $L b$. salivarius $K L-D 4$}

The gene cluster was performed using the primer D4-f2 and the antisense primer D4-R2 located on the upstream and downstream region of the cluster gene, respectively. The reaction of the PCR mixtures $(50 \mu \mathrm{l})$ consisted of about 50-200 ng of genomic DNA used as a template, $10 \mu \mathrm{M}$ of each primer, 1.25 units of PrimeSTAR HS DNA Polymerase, 5X PrimeSTAR buffer $\left(\mathrm{Mg}^{2+}\right.$ plus) and $2.5 \mathrm{mM}$ of dNTPs. The PCR conditions were: denaturation at $94{ }^{\circ} \mathrm{C}$ for $3 \mathrm{~min}$, followed by 30 cycles included denaturation at $98{ }^{\circ} \mathrm{C}$ for $10 \mathrm{~s}$, annealing at $55{ }^{\circ} \mathrm{C}$ for $15 \mathrm{~s}$ and extension at $72{ }^{\circ} \mathrm{C}$ for $1.30 \mathrm{~min}$. PCR product obtained was analysed by agarose gel electrophoresis and further submitted for cloning and nucleotide sequence analysis.

\section{Cloning and DNA sequencing}

All PCR products obtained were purified using a QIAEX II kit (Qiagen, USA). The amplified PCR products performed by the set of SalA $\alpha-\mathrm{f} 1$, SalA $\alpha-\mathrm{r} 1$ and D4-f1, Oligo105 were cloned into pT7Blue-T vector (Novagen, USA) while the rest were cloned into pMD20-T vector (Takara, Japan). All PCR products were ligated using $5 \mu$ of Ligation high Ver. 2 at $16{ }^{\circ} \mathrm{C}$ for $2 \mathrm{~h}$. Ligation products were transformed into E. coli DH5 $\alpha$ according to the transformation method of Sambrook et al. (2001). The positive clones were screened using blue-white colony selection on agar plates and the recombinant plasmids were examined for the presence of the genes related to bacteriocin production using the colony PCR technique as follows. Each positive clone was suspended in $10 \mu \mathrm{l}$ of $2 X$ EmeraldAmp PCR Mastermix (Takara Bio Inc., Japan) and $2 \mu \mathrm{l}$ of each primer. The PCR conditions were: denaturation at $94{ }^{\circ} \mathrm{C}$ for $5 \mathrm{~min}, 35$ cycles included denaturation at $94{ }^{\circ} \mathrm{C}$ for $10 \mathrm{~s}$, annealing at $55^{\circ} \mathrm{C}$ for $30 \mathrm{~s}$ and extension at $72{ }^{\circ} \mathrm{C}$ for $2 \mathrm{~min}$. The recombinant plasmid of the positive clone was extracted using a FlexiPrep ${ }^{\mathrm{TM}}$ kit (Amersham Biosciences, USA) and sequenced by the modified method of Sanger and Coulson (1975) using a LI-COR automated DNA sequencer model 4200 (Li-COR Biosciences, USA).

\section{Data analysis}

Database searches were performed using blastx in the BLAST program of the National Center for Biotechnology Information (NCBI; http://www.ncbi.nlm.nih.gov/BLAST). Open reading frame analysis was performed using the ORF finder program (http://www. ncbi.nlm.nih.gov/gorf/gorf.html). Peptide property predictions were performed using a 
peptide property calculator program (Innovagen, http://www.pepcalc.com). Nucleotide sequences alignment was performed using the GENETYX-MAC software (GENETYX ${ }^{\circledR}$, Japan). Promoter prediction was performed using the Neural Network Promoter Prediction software (http://www.fruitfly.org/seq_tools/promoter.html). Protein sequences alignment was performed using the BioEdit Sequence Alignment Editor program V.7.0.0 (http://www.mbio.ncsu.edu/BioEdit/bioedit.html).

\section{Bacteriocin purification}

Purification method

According to the modified method of Flynn et al. (2002), the bacteriocin was purified by three steps of purification, consisting of an ammonium sulfate precipitation, cation exchange chromatography and reverse-phase HPLC. All fractions collected were determined for bacteriocin activity using Lb. sakei subsp. sakei JCM $1157^{\mathrm{T}}$ as an indicator strain.

\section{Ammonium sulfate precipitation}

One liter of CFS from $16 \mathrm{~h}$ culture grown in MRS and $0.5 \%(\mathrm{w} / \mathrm{v})$ of $\mathrm{CaCO}_{3}$ at $37^{\circ} \mathrm{C}$ under shaking conditions at $120 \mathrm{rpm}$ was heated at $70{ }^{\circ} \mathrm{C}$ for $30 \mathrm{~min}$ and subsequently cooled down to $4{ }^{\circ} \mathrm{C}$. The bacteriocin precipitation was achieved using $20 \%(\mathrm{w} / \mathrm{v})$ saturated ammonium sulfate (Univa, Australia) and stirred at $4{ }^{\circ} \mathrm{C}$ for $18 \mathrm{~h}$. The bacteriocin pellets were collected by centrifugation at $4400 \times g$ for $20 \mathrm{~min}$ and dissolved in $1 \mathrm{l}$ of $20 \mathrm{mM}$ citrate buffer $\mathrm{pH} 5.5$ to dilute salt concentration.

\section{Cation exchange chromatography}

Cation exchange chromatography was performed using a fast protein liquid chromatography (FPLC) system (ÄKTA ${ }^{\mathrm{TM}}$ explorer, model 900, Amersham Bioscience, USA) with the Unicorn V.5.01 software. The UV detection used in this step was carried out at $220 \mathrm{~nm}$. One liter of AMS solution from ammonium sulfate precipitation was applied into $20 \mathrm{ml}$ of the strong cation exchange resin (SP Sepharose Fast Flow, Amersham, Sweden) packed in a XK16 column (Amersham Bioscience, USA) at a flow rate of $2 \mathrm{ml} / \mathrm{min}$ and washed with $3 \times$ column volume of $20 \mathrm{mM}$ citrate buffer $\mathrm{pH} 5.5$ at the flow rate of $1 \mathrm{ml} / \mathrm{min}$. One-step elution of $20 \mathrm{ml}$ buffer containing $0.8 \mathrm{M} \mathrm{NaCl}$ was used to obtain the bacteriocin solution.

\section{Reverse-phase HPLC}

This process was performed using the Breeze 2 System (Walter, USA), including a binary pump: model 1525 (Walter, USA), a 6 port injector: model 7725 (Rheodyn, USA), a UV/ visible detector: model 2489 (Walter, USA) and a computer with the Breeze software installed. The bacteriocin separation was achieved using a Resource RPC $3 \mathrm{ml}$ column (Amersham Bioscience, Sweden) at the flow rate of $1 \mathrm{ml} / \mathrm{min}$. The injection sample volume was $5 \mathrm{ml}$. Two mobile phase systems were used and consisted of solvent A $(0.1 \%$ $(\mathrm{v} / \mathrm{v})$ trifluoroacetic acid (TFA) in deionized water) and solvent $\mathrm{B}$ (acetonitrile containing $0.1 \%$ TFA). Five milliliters of bioactive fractions obtained from cation exchange chromatography was subjected to the Resource RPC column equilibrated with $3 \mathrm{X}$ column volume of solvent A. Elution was then carried out with a linear gradient of $100 \% \mathrm{~A} / 0 \% \mathrm{~B}$ to 
$0 \% \mathrm{~A} / 100 \% \mathrm{~B}$ for $30 \mathrm{~min}$. The active fractions were subjected to RP-HPLC a second time to obtain the pure bacteriocin. The residual acetonitrile was removed by using a speed vacuum concentrator (Uivapo100H, Uniequip, Germany) before testing the bacteriocin activity and applying it for SDS-PAGE.

\section{Determination of protein concentration}

Protein concentrations were determined using a Bio-Rad protein Assay kit (Bio-Rad, USA), which was based on the Bradford method (Kruger 2002).

\section{Tris-Tricine SDS-PAGE}

An active fraction was subjected to $15 \%(\mathrm{w} / \mathrm{v})$ polyacrylamide-gel electrophoresis as described by Bollage and Edelstein (1991) using a Tris-Tricine buffer system performed according to the manufacturer's instruction of the Mi-Protean ${ }^{\circledR}$ Tetra system (Bio-Rad, USA) at $100 \mathrm{~V}$ for $45 \mathrm{~min}$. Fermentas Spectra ${ }^{\mathrm{TM}}$ Multicolor Low Range Protein Ladder (Thermo Scientific, USA) was used to estimate the molecular weight of the pure bacteriocin. The gel was stained using a Pierce ${ }^{\circledR}$ Silver stain kit (Thermo Scientific, USA).

\section{Zymogram analysis}

A zymogram of bacteriocin was performed as described by Losteinkit et al. (2001). After electrophoresis, the gel was divided into two parts. The first part was stained with the silver stain kit to check the bacteriocin purity. The second part was used to determine the activity against $L b$. sakei subsp. sakei JCM $1157^{\mathrm{T}}$ by washing three times with sterilized water for $10 \mathrm{~min}$ and subsequently placing on MRS agar containing the target strain to obtain a clear zone.

\section{Preparation of bacteriocin-treated bacterial contaminating Filling}

To prepare partially purified salivaricin KLD (PP-KLD), $1 \mathrm{~L}$ of CFS from $16 \mathrm{~h}$ culture grown in MRS and $0.5 \%(\mathrm{w} / \mathrm{v})$ of $\mathrm{CaCO}_{3}$ at $37{ }^{\circ} \mathrm{C}$ under shaking conditions at $120 \mathrm{rpm}$ was heated at $70{ }^{\circ} \mathrm{C}$ for $30 \mathrm{~min}$ and cooled down to $4{ }^{\circ} \mathrm{C}$. The bacteriocin was precipitated using $20 \%$ saturated ammonium sulfate (Univa, Australia), stirring at $4{ }^{\circ} \mathrm{C}$ for $18 \mathrm{~h}$ and centrifuging at $4400 \times g$ for $20 \mathrm{~min}$. Subsequently, the bacteriocin pellets obtained were dissolved in $20 \mathrm{ml}$ of $20 \mathrm{mM}$ citrate buffer pH 5.5 and later freeze dried (FD50 Series, Epsilon, Thailand). The freeze-drying was performed under a vacuum as follows: pre-freeze at $-35{ }^{\circ} \mathrm{C}$ for $3 \mathrm{~h}$, main drying at $-35,10$ and $25^{\circ} \mathrm{C}$ for 2,6 and $6 \mathrm{~h}$, respectively, and final drying at $35^{\circ} \mathrm{C}$ for $13 \mathrm{~h}$. The inhibitory activities of $800,000 \mathrm{AU} / \mathrm{g}$ against Lb. sakei subsp. sakei JCM $1157^{\mathrm{T}}$ were obtained.

To prepare creamy filling, $1 \mathrm{~g}$ of the filling consisting of evaporated milk $(0.30 \mathrm{~g})$, egg $(0.10 \mathrm{~g})$, sucrose $(0.18 \mathrm{~g})$, corn flour $(0.06 \mathrm{~g})$ and butter $(0.06 \mathrm{~g})$ was mixed well at $60-70{ }^{\circ} \mathrm{C}$ for $10 \mathrm{~min}$ and then sterilizing by autoclaving at $121^{\circ} \mathrm{C}$ for $15 \mathrm{~min}$. Then, $0.3 \mathrm{ml}$ of PP-KLD to obtain the final concentrations of 1,5 and $10 \%$ by weight of filling (w/w), $1 \%(\mathrm{w} / \mathrm{w})$ of commercial food preservative $\mathrm{H}-3$ (Asama Chemical, Japan) and $2 \%(\mathrm{w} / \mathrm{w})$ of glycine (Yuki Gosei Kogyo, Japan) were added and mixed well. The concentration of commercial products used was the maximum that do not effect to the taste of products. Sterilized distilled water was added instead of AMS and used as a negative control. 
To perform bacterial contamination, a single colony of each target strain was inoculated in $5 \mathrm{ml}$ of nutrient broth (NB) and incubated at $37^{\circ} \mathrm{C}$ for $16 \mathrm{~h}$ under shaking conditions at $150 \mathrm{rpm}$. Subsequently, $10 \mu \mathrm{l}$ of each target strain was inoculated into the filling and AMS-treated filling to obtain the final cell concentration of $5 \log \mathrm{CFU} / \mathrm{g}$ and then mixed well using a stomacher (Seward, England) at normal speed for $1 \mathrm{~min}$. All treatments were incubated at $37{ }^{\circ} \mathrm{C}$ for 3 days. Total viable counts at 0 and 3 days were determined by the standard plate-count method (Wehr and Frank 2004). Each treatment was performed for two replications. The growth inhibitory efficiency (GIE) in the filling was evaluated according to the modified method of Wongsuttichote and Nitisinprasert (2009) using the equation:

$$
\mathrm{GIE}=\frac{\mathrm{C}_{\mathrm{c}}-\mathrm{C}_{\mathrm{t}}}{\mathrm{C}_{\mathrm{c}}} \times 100
$$

where $\mathrm{C}_{\mathrm{c}}$ and $\mathrm{C}_{\mathrm{t}}$ are $\log \mathrm{CFU}$ of the control (without AMS) and the treatment (addition of AMS) at each condition, respectively.

\section{Statistical analysis}

The average values from the duplicate experiments were determined using an Excel program (Microsoft Corp., USA). To determine the standard deviations and statistical significance of data, a one-way ANOVA was performed at the $95 \%$ confidence interval $(P<0.05)$ using the SPSS statistical package version 22 (IBM Corp., USA).

\section{Results}

\section{Preliminary identification of antimicrobial substance from Lb. salivarius KL-D4}

The inhibitory activity of a KL-D4 strain was completely eliminated when the culture solution was treated with all proteolytic enzymes except amylase and lipase (Table 3). These results strongly indicated that the AMS is a proteinaceous structure corresponding to the bacteriocin definition (Klaenhammer 1993). Therefore, this AMS produced by the KL-D4 strain was a bacteriocin.

\section{Effect of $\mathrm{CaCO}_{3}$ and agitation to cell growth and bacteriocin production}

The effects of the $\mathrm{CaCO}_{3}$ added to neutralize the lactic acid during growth and low agitation at $120 \mathrm{rpm}$ were determined under four different conditions: shaking at at low velocity of $120 \mathrm{rpm}(\mathrm{SK})$, shaking at $120 \mathrm{rpm}$ supplemented with $0.5 \%(\mathrm{w} / \mathrm{v})$ of $\mathrm{CaCO}_{3}$ $(\mathrm{SK}+\mathrm{Ca})$, static conditions $(\mathrm{ST})$ and static conditions supplemented with $0.5 \%(\mathrm{w} / \mathrm{v})$ of $\mathrm{CaCO}_{3}(\mathrm{ST}+\mathrm{Ca})$. The results were shown in Fig. 1a, b. The growth of all conditions were increased dramatically at log phase and approached the stationary phase since $6 \mathrm{~h}$. Their viable cell concentrations decreased at 15-18 h. The ST + Ca condition showed higher viable cell than the ST condition at stationary phase. While the $\mathrm{pH}$ of without calcium carbonate of both conditions (3.81-3.89) decreased more than the one with calcium carbonate (4.37-4.6) consequently affecting higher survival cells of fermentation with calcium carbonate addition due to acid accumulation. However, both static conditions produced the maximum bacteriocin level in the log phase within $6 \mathrm{~h}\left(1.28 \times 10^{4} \mathrm{AU} / \mathrm{ml}\right)$ and then gradually decreased in the stationary phase after $15 \mathrm{~h}$ (Fig. 1a). While shaking conditions with $\mathrm{Ca}$ produced higher bacteriocin activities of $2.56 \times 10^{4} \mathrm{AU} / \mathrm{ml}$ in the 
Table 3 Inhibitory activities against Lactobacillus sakei subsp. sakei jcm $1157^{\top}$ of cell free supernatant under various conditions

\begin{tabular}{|c|c|}
\hline Treatment & Activity $(\mathrm{AU} / \mathrm{ml})$ \\
\hline \multicolumn{2}{|l|}{ Enzymatic stability } \\
\hline Control & 12,800 \\
\hline Protenase K pH 8.0 & 0 \\
\hline Pepsin pH 3.0 & 0 \\
\hline Trypsin pH 8.5 & 0 \\
\hline a-chymotrypsin pH 8.5 & 0 \\
\hline Actinase E pH 7.0 & 0 \\
\hline a-amylase $\mathrm{pH} 7.0$ & 12,800 \\
\hline Lipase pH 7.0 & 12,800 \\
\hline \multicolumn{2}{|l|}{ Heat stability } \\
\hline $100^{\circ} \mathrm{C}$ for $5 \mathrm{~min}, \mathrm{pH} 5.5$ & 25,600 \\
\hline $100^{\circ} \mathrm{C}$ for $30 \mathrm{~min}, \mathrm{pH} 5.5$ & 25,600 \\
\hline $121^{\circ} \mathrm{C}$ for $15 \mathrm{~min}, \mathrm{pH} 5.5$ & 25,600 \\
\hline \multicolumn{2}{|l|}{ pH stability } \\
\hline $\mathrm{pH} 3.0$ & 12,800 \\
\hline $\mathrm{pH} 4.0$ & 12,800 \\
\hline $\mathrm{pH} 5.0$ & 12,800 \\
\hline $\mathrm{pH} 5.5$ & 25,600 \\
\hline $\mathrm{pH} 6.0$ & 25,600 \\
\hline $\mathrm{pH} 7.0$ & 25,600 \\
\hline $\mathrm{pH} 8.0$ & 12,800 \\
\hline pH 9.0 & 12,800 \\
\hline $\mathrm{pH} 10.0$ & 12,800 \\
\hline
\end{tabular}

middle log phase (6 h) (Fig. 1b). However, the specific growth rates of all conditions were not significantly different $(P>0.05)$ shown in Table 4 . Therefore, it was clearly shown that the $\mathrm{SK}+\mathrm{Ca}$ condition displayed higher bacteriocin activities than the static conditions for twofold even their growth rate were not different.

\section{Effect of $\mathrm{pH}$ and heat treatment}

The results are shown in Table 3 with stability over a wide $\mathrm{pH}$ range of 3.0-10.0 with $100 \%$ stability of $25,600 \mathrm{AU} / \mathrm{ml}$ in the $\mathrm{pH}$ range of 5.5-7.0. Moreover, the bacteriocin activities of $25,600 \mathrm{AU} / \mathrm{ml}$ at $100{ }^{\circ} \mathrm{C}$ for 5 and $30 \mathrm{~min}$ and by autoclaving at $121{ }^{\circ} \mathrm{C}$ for 15 min still remained at $100 \%$.

Inhibitory spectrum of cell free supernatant and partially purified bacteriocin

The CFS levels adjusted to $\mathrm{pH} 5.5$ were determined for inhibitory activity against 17 bacterial strains of both Gram-positive and Gram-negative bacteria (Table 5). All lactic acid bacteria (LAB) tested were inhibited. The most sensitive strain was Lb. sakei subsp. sakei JCM1 $157^{\mathrm{T}}$. However, the bacteriocin could not inhibit the growth of Bacillus coagulans TISTR1447, Brochotrix campeatris NBRC11547, Streptococcus sp. TISTR1030, Aeromonas hydrophila TISTR1321, Stenotrophomonas sp. KUB-E2, Escherichia coli O157:H7 and Salmonella enterica serovar Enteritidis DMST17368. 


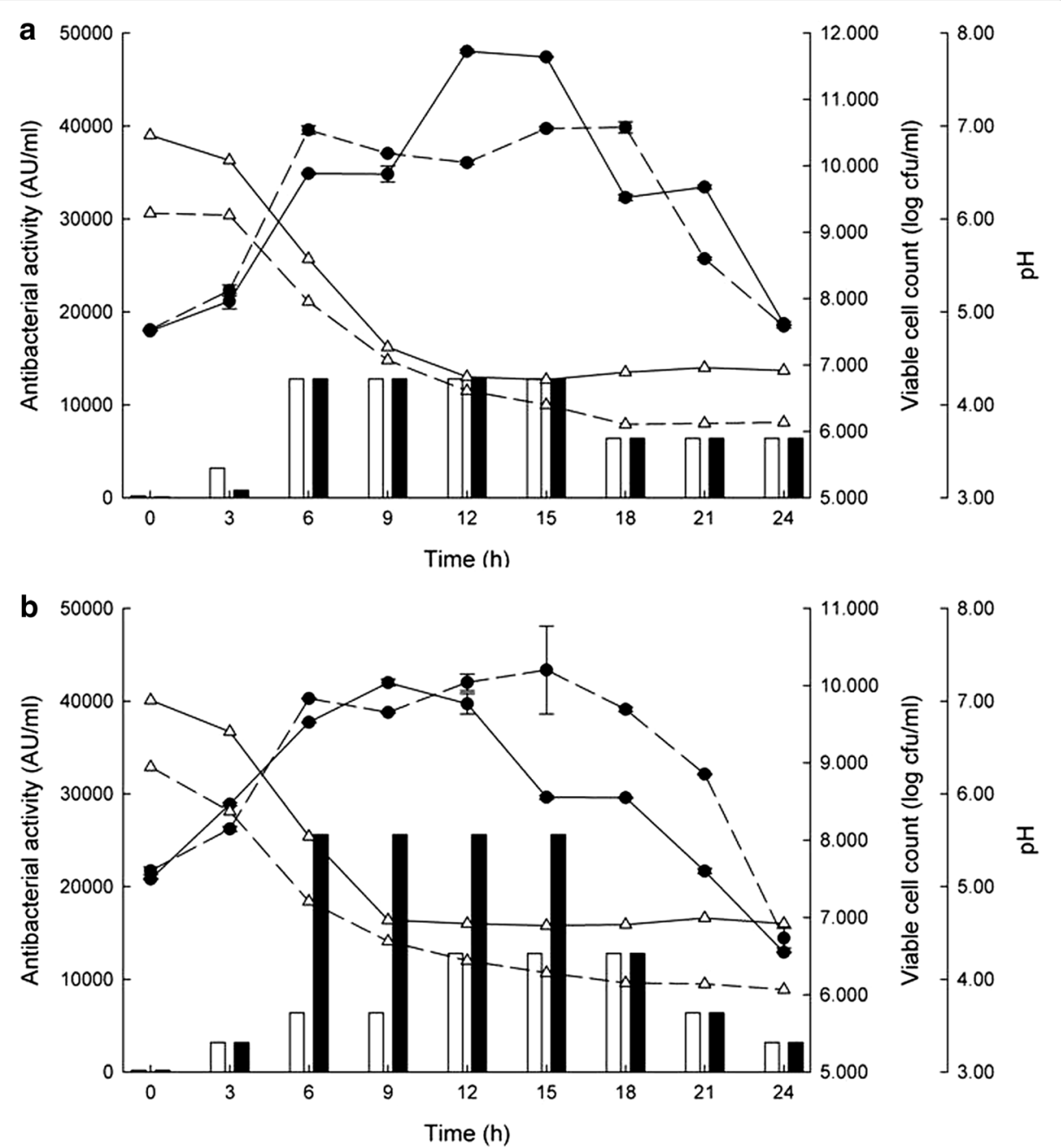

Fig. 1 Growth and bacteriocin production by Lb. salivarius KL-D4 in MRS broth. Static condition (a); shaking condition with $120 \mathrm{rpm}(\mathbf{b})$; supplementation with $\mathrm{CaCO}_{3}$, solid line; with out $\mathrm{CaCO}_{3}$, dash line; $\mathrm{pH}$ during fermentation, (triangle); viable cells determined by standard plate count method, (black circle); black bars and white ones are antibacterial activities from culture grown in MRS supplement with and without $\mathrm{CaCO}_{3}$, respectively

Table 4 Specific growth rate of bacteriocin producing Lb. salivarius KL-D4 grown in MRS medium with and without $\mathrm{CaCO}_{3}$ at $37^{\circ} \mathrm{C}$ under static and shaking condition

\begin{tabular}{ll}
\hline Condition & Specific growth rate $(\boldsymbol{\mu})$ \\
\hline Static condition (ST) & $0.09 \pm 0.01$ \\
Static condition with $0.5 \%(\mathrm{~W} / \mathrm{v})$ of $\mathrm{CaCO}_{3}(\mathrm{ST}+\mathrm{Ca})$ & $0.08 \pm 0.01$ \\
Shaking at $120 \mathrm{rpm}(\mathrm{SK})$ & $0.06 \pm 0.00$ \\
Shaking at $120 \mathrm{rpm}$ with $0.5 \%(\mathrm{w} / \mathrm{v})$ of $\mathrm{CaCO}_{3}(\mathrm{SK}+\mathrm{Ca})$ & $0.04 \pm 0.00$ \\
\hline
\end{tabular}

Partially purified salivaricin KLD (PP-KLD) using $20 \%(\mathrm{w} / \mathrm{v})$ saturated ammonium sulfate precipitation exhibited high activities against Enterococcus faecalis KUB-E5 and E. faecalis KUB-E7, which were isolated from the éclair production process. It was interesting that bacteriocin in the form of CFS and partially purified bacteriocin exhibited 
Table 5 Inhibitory activities of cell free supernatant and partial purified salivaricin KLD against various target strains

\begin{tabular}{|c|c|}
\hline Indicator strain & Inhibitory activity (AU/ml) \\
\hline \multicolumn{2}{|l|}{ Lactic acid bacteria ${ }^{1}$} \\
\hline Lactococcus lactis subsp. cremoris TISTR1344 & 800 \\
\hline Lactobacillus plantarum ATCC14917 & 200 \\
\hline Lactobacillus sakei subsp. Sakei JCM1157 & 25,600 \\
\hline Lactobacillus sakei TISTR 890 & 100 \\
\hline Leuconostoc mesenteroides subsp. mesenteroides JCM6124 & 400 \\
\hline Leuconostoc mesenteroides subsp. mesenteroides TISTR942 & 800 \\
\hline \multicolumn{2}{|l|}{ Other Gram-positive bacteria ${ }^{1}$} \\
\hline Bacillus cereus JCM2152 & 3200 \\
\hline Bacillus coagulans JCM2257 & 100 \\
\hline Bacillus coagulans TISTR1447 & 0 \\
\hline Brochotrix campeatris NBRC11547 & 0 \\
\hline Listeria innocua ATCC33090 & 6400 \\
\hline Streptococcus sp. TISTR1030 & 0 \\
\hline \multicolumn{2}{|l|}{ Gram-negative bacteria $^{1}$} \\
\hline Aeromonas hydrophila TISTR1321 & 0 \\
\hline Escherichia coli O157:H7 & 0 \\
\hline Pseudomonas fluorescens JCM5963 & 800 \\
\hline Pseudomonas fluorescens TISTR358 & 800 \\
\hline Salmonella enterica serova Enteritidis DMST17368 & 0 \\
\hline \multicolumn{2}{|l|}{ Bacterial contaminants from Éclair product ${ }^{2}$} \\
\hline Enterococcus fecalis KUB-E5 & 12,800 \\
\hline Enterococcus fecalis KUB-E7 & 12,800 \\
\hline Staphylococcus epidermidis KUB-E6 & 800 \\
\hline Staphylococcus hominis KUB-E8 & 3200 \\
\hline Pseudomonas stutzeri KUB-E1 & 1600 \\
\hline Stenotrophomonas sp. KUB-E2 & 0 \\
\hline
\end{tabular}

The strain KUB-E1, -E2, -E5, -E6, -E7 and -E8 isolated from éclair production process and deposited in theculture collection of the Specialized Research Unit: Probiotics and Prebiotics for Health, Department of Biotechnology, Kasetsart University, Thailand

ATCC American Type Culture Collection, Rockville, Md; DMST Department of Medical Science Thailand, Thailand; JCM Japanese Culture of Microorganism, Wako, Japan; NBRC National Institute of Technology and Evaluation (NITE) Biological Resource Center; TISTR Thailand Institute of Scientific and Technological Research

a Activities determination of CFS

${ }^{b}$ Activities determination of KLD

inhibitory activities of 800 and $1600 \mathrm{AU} / \mathrm{ml}$, respectively, against Pseudomonas fluorescens and P. stutzeri which were Gram-negative bacteria as well.

\section{Identification of bacteriocin from $L b$. salivarius KL-D4 by polymerase chain reaction}

Lactobacillus salivarius, the candidate of the bacteriocin producer strain, was discovered many years ago (Messaoudi et al. 2013). Some of these species could produce a bacteriocin named salivacin or salivaricin (Barrett et al. 2007; Flynn et al. 2002; Matsusaki et al. 2006; Ocaña et al. 1999; Pilasombut et al. 2006). In this study, the first reaction of the PCR walking technique was performed using the primers SalA $\alpha$-f1 and SalA $\alpha-\mathrm{r} 1$ resulting in one ORF named $k l d 1$ which exhibits $100 \%$ identity to the gene encoding for the uncharacterized bacteriocin $\alpha$ peptide of Lb. salivarius GJ-24 (Accession No. EGM49654.1). However, it displayed $94 \%$ identity to the gene encoding Abp118 $\alpha$ of $L b$. 
salivarius (Accession No. AAM61778.1). The kld1 sequence of Lb. salivarius KL-D4 was submitted into GenBank of the NCBI database with Accession No. KT307081 on July 16th, 2015. Its molecular weight of 4.202 and isoelectric focusing point of 9.02 (by a peptide property calculator program) were different to other salivaricins $\alpha$ of 4.0 and 8.58, respectively (Barrett et al. 2007; Cho et al. 2011; Flynn et al. 2002; Matsusaki et al. 2006; Ocaña et al. 1999; Pilasombut et al. 2006).

Further walking was done using the primer D4-f1 and Oligo105 designed from kld1 and the degenerate primer based on histidine kinase of class II bacteriocin (Eijsink et al. 2002; Nissen-Meyer et al. 2010; Oppegrad et al. 2007), respectively, resulting in a $1.8 \mathrm{~kb}$ PCR fragment which contained three ORFs named $k l d 2, k l d 3$ and $k l d 4$. By blast analysis, the $k l d 2, k l d 3$ and $k l d 4$ showed identity of 100,100 and $99 \%$ to the gene encoding uncharacterized bacteriocin $\beta$ peptide (Accession No. EGM49653.1), uncharacterized hypothetical protein (Accession No. EGM49652.1) and Abk transduction sensory histidine protein kinase (Accession No. EGM49651.1) of Lb. salivarius GJ-24 of Lb. salivarius GJ-24, respectively. It seemed that the gene cluster of the strain KL-D4 was similar to the one of GJ-24. However, those kld2, kld3 and kld4 displayed different identities to Abp118 $\beta$ (Accession No. AAM61779.1), the salivaricin induction peptide (Accession No. ABQ84445.1) and the histidine protein kinase (Accession No. AAM61782.1) for 93, 59 and $62 \%$ of other $L b$. salivarius strains, respectively.

To investigate other genes, inverse PCR was performed. Chromosomal DNA of $L b$. salivarius KL-D4 was randomly digested by 9 restriction enzymes. Only SacI digested chromosomal DNA was successfully amplified by the primers D4-f1 and D4-r1 resulting in $2.3 \mathrm{~kb}$ containing an open reading frame of $294 \mathrm{bp}$ named $k l d 5$ and the other pMD$20 \mathrm{~T}$ vector sequences. The $k l d 5$ exhibited $99 \%$ similarity to the gene coding unclarified bacteriocin family from Lb. salivarius GJ-24 (Accession No. EGM49655.1) but not to other salivaricin producing strains.

According to the results above, it could be summarized that $L b$. salivarius KL-D4 has two structural bacteriocin genes similar to Abp118 $\alpha$ and $\beta$ related to the salivaricin family and another two genes to regulation of class-II bacteriocin. Adjacency to the salivaricin gene cluster and confirmation by the primer D4-f2 and the antisense primer D4-r2 are shown in Fig. 2. Two promoter and ribosomal binding sites (RBS) located on the upstream region of $k l d 1$ and $k l d 3$ were found. An open reading frame (ORF) analysis performed using an ORF Finder program confirmed that two structural genes of kld 1 and $k l d 2$ were located on different ORF frames of +1 and +3 , respectively. It seemed that $k l d 2$ did not have its own promoter and RBS for gene expression. It was, therefore, proposed that bacteriocin was expressed by only kld 1 .

\section{Purification of bacteriocin produced by Lb. salivarius KL-D4}

Purification of bacteriocin was achieved by three purification steps as shown in Table 6 . Partial purification by $20 \%$ ammonium sulfate saturation and cation exchange chromatography provided only $1 \%$ yield. The pure bacteriocin was eluted from the reverse phase HPLC with $74 \%$ solvent B (Fig. 3) to obtain purification and yields of 40.68 folds and $0.01 \%$, respectively. By Tris-Tricine SDS-PAGE analysis, only a single protein band of about $4.3 \mathrm{kDa}$ was obtained as shown in Fig. 4, namely salivaricin KLD. 


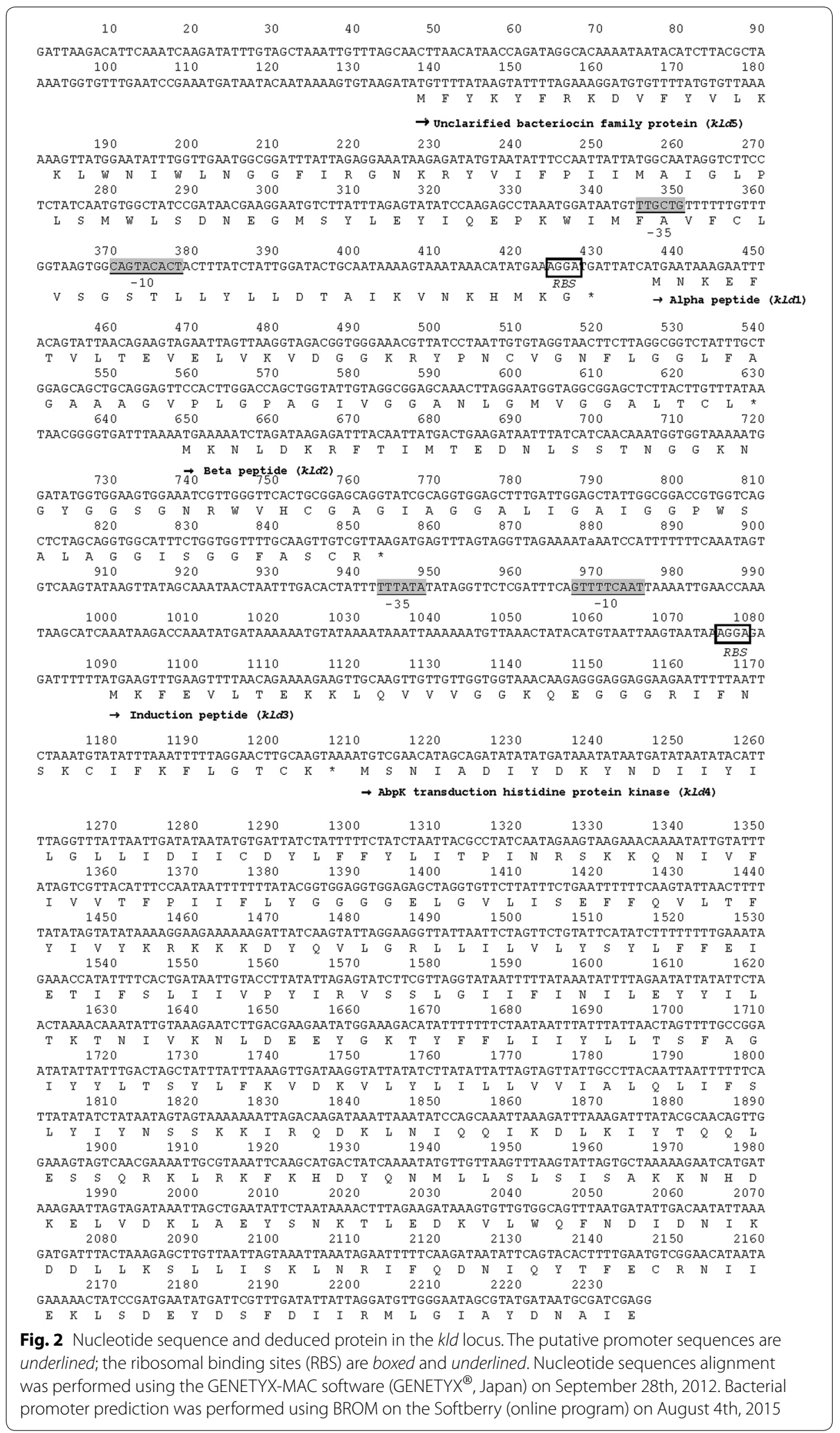


Table 6 Purification table of salivaricin KLD

\begin{tabular}{|c|c|c|c|c|c|c|c|c|}
\hline $\begin{array}{l}\text { Purifica- } \\
\text { tion stage }\end{array}$ & Vol. (ml) & $\begin{array}{l}\text { Activity } \\
\text { (AU/ml) }\end{array}$ & $\begin{array}{l}\text { Protein } \\
\text { concen- } \\
\text { tration } \\
(\mathrm{mg} / \mathrm{ml})\end{array}$ & $\begin{array}{l}\text { Total } \\
\text { protein } \\
(\mathrm{mg})\end{array}$ & $\begin{array}{l}\text { Total } \\
\text { activity } \\
\text { (AU) }\end{array}$ & $\begin{array}{l}\text { Specific } \\
\text { activity } \\
\text { (AU/mg) }\end{array}$ & $\begin{array}{l}\text { Purifi- } \\
\text { cation } \\
\text { (folds) }\end{array}$ & Yield (\%) \\
\hline $\begin{array}{l}\text { Cell free } \\
\text { superna- } \\
\text { tant }\end{array}$ & 1000 & 25,600 & 18.600 & $18,600.000$ & $2.56 \times 10^{7}$ & $1.38 \times 10^{3}$ & 1 & 100 \\
\hline $\begin{array}{l}\left(\mathrm{NH}_{4}\right)_{2} \mathrm{SO}_{4} \\
\text { precipi- } \\
\text { tate }\end{array}$ & 20 & 102,400 & 2.150 & 43.000 & $2.05 \times 10^{6}$ & $4.77 \times 10^{4}$ & 34.57 & 8.01 \\
\hline $\begin{array}{l}\text { Cation } \\
\text { exchange }\end{array}$ & 20 & 12,800 & 0.224 & 4.480 & $2.56 \times 10^{5}$ & $5.71 \times 10^{4}$ & 41.38 & 1.00 \\
\hline RP-HPLC & 1 & 3200 & 0.057 & 0.057 & $3.20 \times 10^{3}$ & $5.61 \times 10^{4}$ & 40.68 & 0.01 \\
\hline
\end{tabular}

All \% yield values are expressed in terms of activity units in the cell free supernatant taken as $100 \%$ while purification values are in the terms of specific activities in the cell free supernatant taken as 1

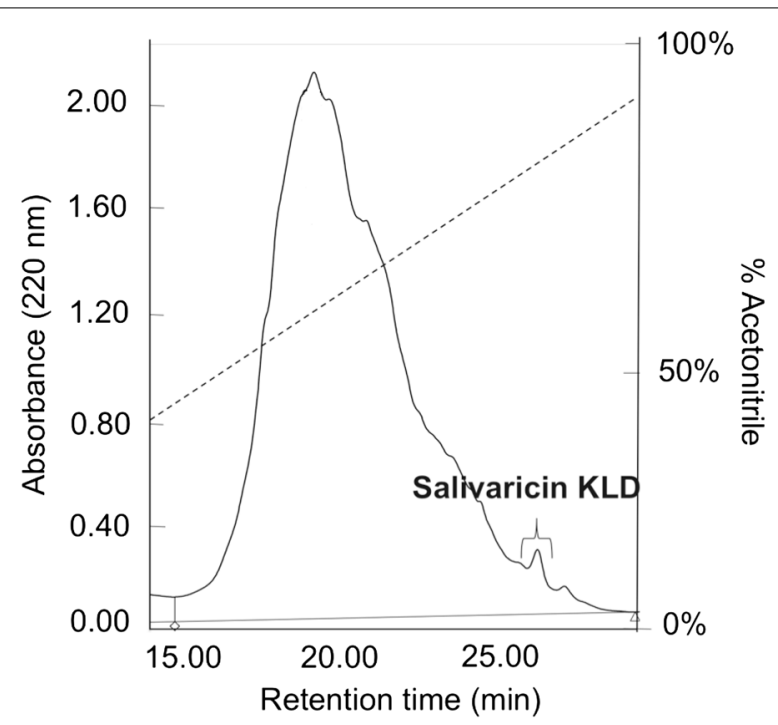

Fig. 3 Reverse-phase chromatogram of the salivaricin KLD. The target fraction (a salivaricin KLD fraction) was earned by eluting with $74 \%$ of solvent B. Dash line is a gradient condition of solvent B (acetonitrile, \%v/v)

\section{Effect of salivaricin KLD on the growth of bacterial contaminants in creamy filling}

The partially purified salivaricin KLD using ammonium sulfate precipitation and freezedrying that exhibited inhibitory activity against bacterial contaminants from the production process of éclair was studied. Six target strains isolated from the production process of E'clair product were used to perform the experiments and the results are summarized in Table 7. The growth inhibitory efficiency (GIE) of 1,5 and $10 \%$ of KLD compared to the efficiency of two commercial bacteriocins, $1 \% \mathrm{H} 3$ and $2 \%$ glycine, were tested at 0 and 3 days as shown in Table 7. Various concentrations of KLD showed high GIE values of 22-39 and 52-100\% against E. faecalis KUB-E5 at 0 and $72 \mathrm{~h}$, respectively, while both the commercial ones displayed only $0.39-1.8 \%$. The activity of KLD against E. faecalis KUB-E7 was lower than against E. faecalis KUB-E5; however, its activity against E. faecalis KUB-E7 was still higher than for the other commercial compounds. 


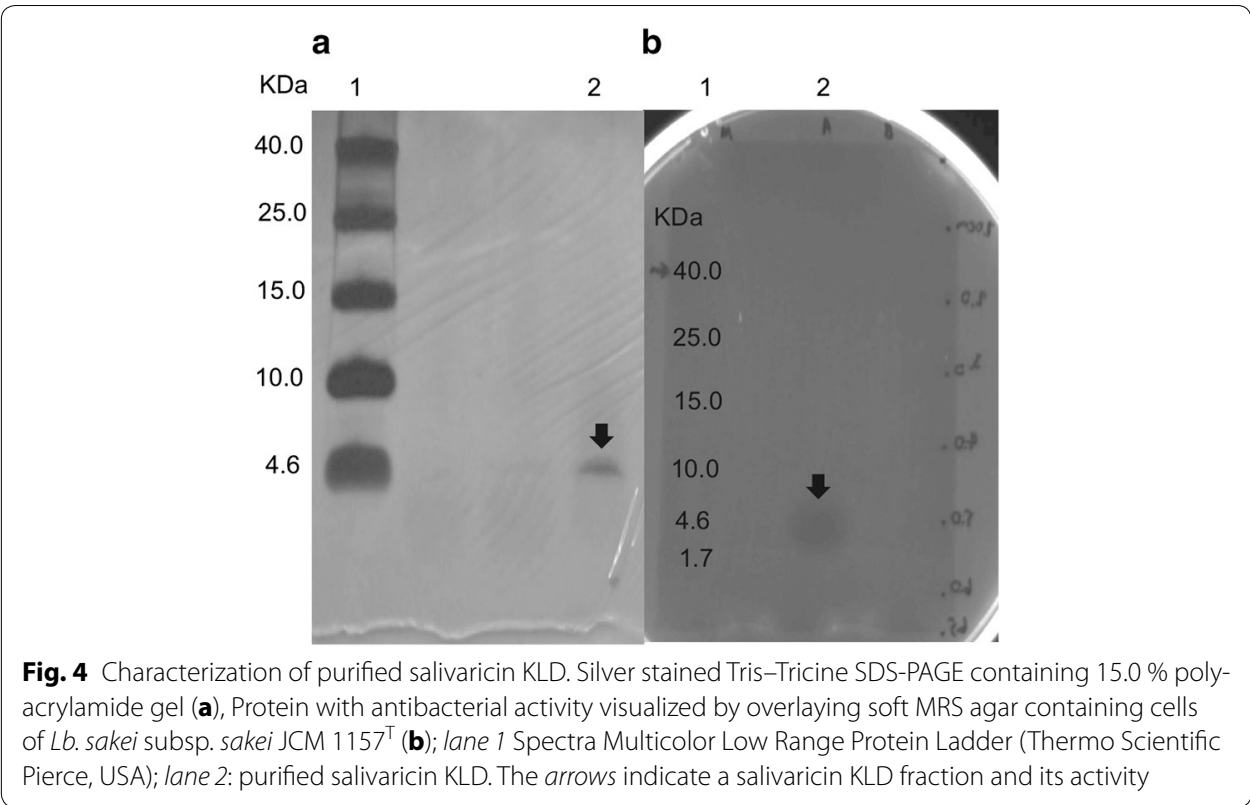

Two species of Staphylococcus (S. epidermidis KUB-E6 and S. hominis KUB-E8) were investigated. The 5 and $10 \%$ concentrations of KLD and the $2 \%$ glycine treatment exhibited significantly higher GIE than the other treatments against the growth of only strain KUB-E8, while the KLD showed no activity to the strain KUB-E6 at $72 \mathrm{~h}$.

Bacillus cereus is a frequent contaminant in bakery products and causes rope spoilage. It was found that $B$. cereus JCM 2152 had significantly $(P<0.05)$ the highest sensitivity to $10 \%$ KLD resulting in GIE values of $10.14 \pm 0.29$ and $66.94 \pm 0.88 \%$ at 0 and $72 \mathrm{~h}$, respectively, while the activities of $5 \% \mathrm{KLD}$ and $1 \% \mathrm{H} 3$ showed no significant difference of GIE at $72 \mathrm{~h}$.

Considering the two Gram-negative bacterial strains of Pseudomonas stutzeri KUBE1 and Stenotrophomonas sp. KUB-E2, P. stutzeri KUB-E1 was more sensitive to 5 and $10 \%$ of KLD at both 0 and $72 \mathrm{~h}$ while $1 \%$ KLD exhibited $100 \%$ GIE at $72 \mathrm{~h}$. Both 5 and $10 \%$ KLD also showed $100 \%$ GIE against Stenotrophomonas sp. KUB-E2 at $72 \mathrm{~h}$. Both commercial AMS products (H3 and glycine) had lower GIE levels against both Gramnegative bacteria compared to the KLD.

\section{Discussion}

A salivaricin KLD produced by $L b$. salivarius KL-D4 showed high resistance to heat, high stability over a wide $\mathrm{pH}$ range of $3.0-10.0$, and a wide antibacterial spectrum against Gram-positive and Gram-negative bacteria. In addition, it should be noted that the salivaricin KLD is stable at high $\mathrm{pH}$ of $8-10$, while nisin, a well-known bacteriocin usually used in the bakery products rapidly loses its activity at a $\mathrm{pH}$ of more than 4 (Rollema et al. 1995). The salivaricin KLD also effectively inhibited spore-forming B. cereus, which often contaminates bakery products, such as custards and cream cakes (Siriken et al. 2009). Therefore, these characteristics are promising for applications of the 
Table 7 Growth inhibitory efficiency of antimicrobial substances against bacterial contaminants in sterilized creamy filling containing about 5 log CFU/g of each target strain and various food preservatives of PP-KLD, H-3 and glycine

\begin{tabular}{|c|c|c|c|}
\hline \multirow[t]{2}{*}{ Target strain } & \multirow{2}{*}{$\begin{array}{l}\text { Treatment } \\
\%(w / w)^{a}\end{array}$} & \multicolumn{2}{|c|}{ Growth inhibitory efficiency (\%) ${ }^{\mathbf{b}}$} \\
\hline & & $\mathrm{Oh}$ & $72 \mathrm{~h}$ \\
\hline \multirow[t]{5}{*}{ Enterococcus fecalis KUB-E5 } & 1 \%PP-KLD & $22.76 \pm 0.82 b$ & $52.27 \pm 2.09 b$ \\
\hline & 5 \%PP-KLD & $39.30 \pm 3.08 c$ & $100.00 \pm 0.00 c$ \\
\hline & $10 \%$ PP-KLD & $26.46 \pm 0.40 b$ & $100.00 \pm 0.00 c$ \\
\hline & $1 \% \mathrm{H}-3$ & $0.39 \pm 0.16 a$ & $1.75 \pm 0.27 a$ \\
\hline & 2 \%Glycine & $1.27 \pm 0.32 a$ & $1.87 \pm 0.45 a$ \\
\hline \multirow[t]{5}{*}{ Enterococcus fecalis KUB-E7 } & 1 \%PP-KLD & $15.40 \pm 3.14 b$ & $11.51 \pm 5.34 b$ \\
\hline & $5 \%$ PP-KLD & $17.83 \pm 2.43 b$ & $30.69 \pm 0.28 c$ \\
\hline & $10 \%$ PP-KLD & $19.96 \pm 0.94 b$ & $60.12 \pm 0.4 d$ \\
\hline & $1 \% \mathrm{PP}-\mathrm{H}-3$ & $1.88 \pm 0.08 a$ & $0.90 \pm 0.13 a$ \\
\hline & 2 \%PP-Glycine & $3.61 \pm 0.39 a$ & $3.89 \pm 0.15 a$ \\
\hline \multirow[t]{5}{*}{ Staphylococcus epidermidis KUB-E6 } & $1 \% \mathrm{KLD}$ & $1.83 \pm 1.02 b$ & $0.00 \pm 0.00 \mathrm{a}$ \\
\hline & $5 \% \mathrm{KLD}$ & $0.46 \pm 2.36 a$ & $0.00 \pm 0.00 a$ \\
\hline & $10 \% \mathrm{KLD}$ & $1.80 \pm 2.55 b$ & $0.00 \pm 0.00 \mathrm{a}$ \\
\hline & $1 \% \mathrm{H}-3$ & $3.24 \pm 0.38 c$ & $24.58 \pm 1.11 b$ \\
\hline & $2 \%$ Glycine & $0.00 \pm 0.00 a$ & $22.37 \pm 1.14 b$ \\
\hline \multirow[t]{5}{*}{ Staphylococcus hominis KUB-E8 } & $1 \%$ PP-KLD & $1.96 \pm 1.95 a$ & $22.91 \pm 0.23 a$ \\
\hline & 5 \%PP-KLD & $3.85 \pm 2.66 a$ & $28.10 \pm 1.38 \mathrm{c}$ \\
\hline & $10 \%$ PP-KLD & $3.37 \pm 0.17 a$ & $25.80 \pm 1.85 c$ \\
\hline & $1 \% \mathrm{H}-3$ & $2.58 \pm 0.18 a$ & $23.05 \pm 0.28 \mathrm{ab}$ \\
\hline & 2 \%Glycine & $10.54 \pm 0.27 b$ & $25.69 \pm 0.28 b c$ \\
\hline \multirow{5}{*}{ Bacillus cereus JCM2152 } & $1 \%$ PP-KLD & $2.02 \pm 1.43 a$ & $4.47 \pm 2.43 \mathrm{a}$ \\
\hline & 5 \%PP-KLD & $6.18 \pm 0.41 b$ & $50.39 \pm 1.58 b$ \\
\hline & $10 \%$ PP-KLD & $10.14 \pm 0.29 c$ & $66.94 \pm 0.88 c$ \\
\hline & $1 \% \mathrm{H}-3$ & $3.28 \pm 0.19 a$ & $44.29 \pm 0.29 b$ \\
\hline & 2 \%Glycine & $8.85 \pm 0.22 \mathrm{c}$ & $6.97 \pm 0.17 a$ \\
\hline \multirow[t]{5}{*}{ Pseudomonas stutzeri KUB-E1 } & 1 \%PP-KLD & $3.92 \pm 5.93 a$ & $100.00 \pm 0.00 c$ \\
\hline & $5 \%$ PP-KLD & $100.00 \pm 0.00 c$ & $100.00 \pm 0.00 c$ \\
\hline & $10 \%$ PP-KLD & $100.00 \pm 0.00 c$ & $100.00 \pm 0.00 c$ \\
\hline & $1 \% \mathrm{H}-3$ & $11.35 \pm 1.15 b$ & $12.53 \pm 0.58 a$ \\
\hline & $2 \%$ Glycine & $14.96 \pm 0.31 b$ & $64.07 \pm 2.34 b$ \\
\hline \multirow[t]{5}{*}{ Stenotrophomonas sp. KUB-E2 } & 1 \%PP-KLD & $0.27 \pm 0.16 a$ & $5.25 \pm 2.56 \mathrm{a}$ \\
\hline & 5 \%PP-KLD & $0.00 \pm 0.00 a$ & $100.00 \pm 0.00 d$ \\
\hline & $10 \%$ PP-KLD & $1.50 \pm 0.40 \mathrm{~b}$ & $100.00 \pm 0.00 d$ \\
\hline & $1 \% \mathrm{H}-3$ & $5.82 \pm 0.05 c$ & $9.04 \pm 0.36 b$ \\
\hline & 2 \%Glycine & $6.24 \pm 0.54 c$ & $44.84 \pm 1.44 c$ \\
\hline
\end{tabular}

All growth efficiency obtained are a mean of two replications $\pm S D(S D) ; a-d$, means in the same column of each target strain with different lower case letters are significantly different $(P<0.05)$

${ }^{a}$ Five treatments of antimicrobial substance PP-KLD at the concentrations of 1,5 and $10 \%, 1 \% \mathrm{H} 3$ and $2 \%$ glycine tested

b Growth inhibitory efficiency defined as percentage of survival cells after antimicrobial substance treatment compared to the control mentioned elsewhere

salivaricin KLD in the creamy production process, as well as in the other bakery lines, which involve alkaline or non acid products.

The salivaricin KLD production was enhanced by culture broth supplemented with $0.5 \%(\mathrm{w} / \mathrm{v}) \mathrm{CaCO}_{3}$ under gentle shaking. The maximum production was observed in the early stationary phase and was maintained until later stages. Its production was 
growth-associated and displayed as primary metabolite kinetic which was similar to almost all bacteriocins produced by lactic acid bacteria (Cheigh et al. 2002; Zamfir et al. 2000). Neutralization of lactic acid in the culture by $\mathrm{CaCO}_{3}$ described by Matsusaki et al. (1996) and increasing the $\mathrm{CaCO}_{3}$ diffusion by gentle shaking could enhance its growth and bacteriocin production as supported by Yamamoto et al. (2003). However, the antibacterial activities observed subsequently decreased in the later stages perhaps due to extracellular proteases produced and acidity during fermentation (Parente and Ricciardi 1999). Bioactivity is usually limited to a narrow time interval of maximum fermentation (about 10-12 h), due to low $\mathrm{pH}$ conditions from the accumulation of lactic acid contents or an exhausted energy source. Then, cell growth and the bacteriocin production will gradually stop. Therefore, both the $\mathrm{pH}$ value and lactic acid production influenced both the cell growth and the bacteriocin-production kinetics, which must be controlled. The genes responsible for the salivaricin KLD production were located on the $2.3 \mathrm{~kb}$ DNA fragment. The cluster of putative genes required for the salivaricin KLD production was similar to other class-IIb bacteriocin gene clusters (Nes et al. 1996). The gene kld1 and $k l d 2$ encoding for pre-peptides salivaricin $\alpha$ and $\beta$ from Lb. salivarius KL-D4 showed high similarity to the ones from $L b$. salivarius GJ-24 isolated from the feces of healthy adults without the characteristics of those peptides reported (Cho et al. 2011). To date, several salivaricins with high structural similarity produced by $L b$. salivarius have been isolated from the intestinal tracts of humans and animals, such as salivaricin ABP-118 produced by the strain UCC118 isolated from human intestines (Flynn et al. 2002), salivaricin CRL1328 produced by the strain CRL1328 isolated from healthy human vaginal samples (Ocaña et al. 1999), salivaricin P produced by the strain DPC6005 isolated from a porcine intestine (Barrett et al. 2007), salivaricin FK22 and salivacin K21 produced by the strain K7 (Pilasombut et al. 2006) and KUB-AC21 isolated from chicken intestines (Matsusaki et al. 2006). Modification of their amino acid sequences occurred depending on the environment of each source and resulted in only $94 \%$ identity to salivaricin KLD which led to different inhibitoty activity against the growth of the Gram-negative bacteria, Pseudomonas and Stenotrophomonas. To date, no salivaricin from other producer strains have been reported regarding their activity against Gram-negative bacteria.

The genes encoding the KLD3 and KLD4 found were located on the DNA fragment and were involved in bacteriocin production called a three-component regulatory system, that includes peptide pheromone (induction peptide, IF) and histidine protein kinase (HPK) (Diep et al. 2003; Eijsink et al. 2002; Kleerebezem and Quadri 2001). However, $k l d 3$ showed only low identity to the peptide pheromone reported, while it induced higher bacteriocin production of up to $25,600 \mathrm{AU} / \mathrm{ml}$ compared to the other Lb. salivarius strain reported. This supported a strong induction peptide coded by kld3. However, other genes related with immunity were not observed by this study. Salivaricin KLD was previously tested for its inhibitory activity against its own producer strain resulting in no inhibition. Therefore, the gene encoding IM of the KL-D4 strain may exist but be located elsewhere on chromosomal DNA, which is different to salivaricin APB-118 (Flynn et al. 2002), salivaricin P (Barrett et al. 2007), salivaricin CRL1328 (Vera Pingitore et al. 2009), and salivacin K21 (Matsusaki et al. 2006) which are located near the structural salivaricin peptide gene. 
Only salivaricin KLD similar to $\alpha$ peptide was expressed and produced by Lb. salivarius KL-D4. This result was similar to Messaoudi et al. (2013) and Flynn et al. (2002) who reported the detection of $\alpha$ peptide in their purification process, while $\beta$ peptide could be produced by $L b$. salivarius K7 (Pilasombut et al. 2006). However, both $\alpha$ and $\beta$ peptides were produced by $L b$. salivarius DPC6005 and successfully purified by RP-HPLC (Barrett et al. 2007).

The salivaricin KLD showed high stability within the $\mathrm{pH}$ range 5.5-7.0. These properties would make it useful as a biopreservative in low acid food such as bakery products classified as non-acidic (Smith et al. 2004). In a tropical country like Thailand, the contaminant cell concentration can be as high as up to $5 \log$ CFU/g in cream-filled products which differs from the European zone where lower numbers of 1-4 log CFU/g have been reported (Leitenberger and Rocken 1998; Siriken et al. 2009). PP-KLD showed remarkable effective inhibition to contaminant strains of B. cereus, E. fecalis, P. stutzeri, as well as Stenotrophomonas sp. Furthermore, the effective inhibition was superior to the commercial bacteriocins of H-3 and glycine. However, both PP-KLD and the commercial bacteriocins were not active against Staphylococcus species. This might have been negatively influenced by the high incubation temperatures promoting faster growth of Staphylococcus (Viedma et al. 2009), which corresponded with the antimicrobial substance PP-174 produced by $L b$. plantarum KJ-174 showing low inhibitory efficiency in cream filling against aerobic mesophilic bacteria, when the incubation temperature was increased from 15 to $37^{\circ} \mathrm{C}$ (Wongsuttichote and Nitisinprasert 2009). To solve this problem, combined preservation called hurdle technology (Cleveland et al. 2001) will be needed to achieve successful preservation in future work.

\section{Conclusion}

Salivaricin KLD shares functional properties of the bacteriocin $\alpha$ peptide that is heat tolerant, stable at a wide $\mathrm{pH}$ range, and exhibited widely antibacterial spectrum. Partial purification by $20 \%$ ammonium sulfate precipitation of the product named PP-KLD was tested on the artificial contamination of creamy filling. The $5 \%$ PP-KLD (w/w) exhibited effective growth inhibitory efficiency against Pseudomonas sp., P. stutzeri, Stenotrophomonas sp. and some strain of E. faecalis but showed low activities against B. cereus, Staphylococcus epidermidis and Staphylococcus hominis. To complete inhibitory activity against microbial contaminants, cooperation with other hurdle technology may be considered in the future.

Authors' contributions

PT, to perform a part of experiments and manuscript preparation; $C T$, to perform a part of experiments; KP, involve in experimental discussion; HM, involve in experimental discussion; SK, involve in experimental discussion and SN, involve in experimental design and discussion as well as manuscript preparation. All authors read and approved the final manuscript.

\section{Author details}

1 Specialized Research Unit, Probiotics and Prebiotics for Health, Department of Biotechnology, Faculty of Agro-Industry, Kasetsart University, Bangkok 10900, Thailand. ${ }^{2}$ Center for Advanced Studies for Agriculture and Food (CASAF), Kasetsart University Institute for Advanced Studies (NRU-KU), Kasetsart University, Bangkok 10900, Thailand. ${ }^{3}$ Division of Animal Production Technology, Faculty of Agricultural Technology, King Mongkut's Institute of Technology Ladkrabang, Bangkok 10520, Thailand. ${ }^{4}$ Department of Food and Health Sciences, Faculty of Environmental and Symbiotic Sciences, Prefectural University of Kumamoto, Kumamoto 862-8502, Japan.

Acknowledgements

We express our gratitude to the Center for Advanced Studies for Agriculture and Food, Institute for Advanced Studies, Kasetsart University, under the Higher Education Research Promotion and the National Research University Project of 
Thailand, Office of the Higher Education Commission, Ministry of Education, Thailand. Our thanks also go to the Division of Animal Production Technology, Faculty of Agricultural Technology, King Mongkut's Institute of Technology Ladkrabang, Bangkok, Thailand the Department of Food and Health Sciences, Faculty of Environmental and Symbiotic Sciences, Prefectural University of Kumamoto, Kumamoto, Japan and the Core-to-Core Program supported by Japan Society for the Promotion of Science (JSPS), National Research Council of Thailand (NRCT), Vietnam Ministry of Science and Technology (MOST), the National University of Laos, Beuth University of Applied Sciences and Brawijaya University.

\section{Competing interests}

The authors declare that they have no competing interests.

\section{Funding}

This study was funded by the Center for Advanced Studies for Agriculture and Food, Institute for Advanced Studies, Kasetsart University, under the Higher Education Research Promotion and the National Research University Project of Thailand, Office of the Higher Education Commission, Ministry of Education, Thailand.

\section{Informed consent}

An informed consent was obtained from all individual participants included in the study.

Received: 8 December 2015 Accepted: 28 June 2016

Published online: 12 July 2016

\section{References}

Barrett E, Hayes M, O'Connor P, Gardiner G, Fitzgerald GF, Stanton C, Ross RP, Hill C (2007) Salivaricin P, one of a family of two-component antilisterial bacteriocins produced by intestinal isolated of Lactobacillus salivarius. Appl Environ Microbiol 73:2719-2723

Bollage DM, Edelstein SJ (1991) SDS-polyacrylamide gel electrophoresis (Linear Slab Gel). Protein methods. Wiley-Liss Inc., New York, pp 96-127

Cheigh Cl, Choi HJ, Park H, Kim SH, Kook MC, Kim TS, Hwang JK, Pyun YR (2002) Influence of growth conditions on the production of a nisin-like bacteriocin by Lactococcus lactis subsp. lactis A164 isolated from Kimchi. J Biotechnol 95:225-235

Chen H, Hoover DG (2003) Bacteriocins and their food applications (2). Comprehensive reviews in food science and food safety. Institute of Food Technologists, Chicago, pp 82-100

Cho YJ, Choi JK, Kim JH, Lim YS, Ham JS, Kang DK, Chun J, Paik HD, Kim GB (2011) Genome sequence of Lactobacillus salivarius GJ-24, a probiotic strain isolated from healthy adult intestine. J Bacteriol 2011:5021-5022

Cleveland J, Montville TJ, Nes IF, Chikindas ML (2001) Bacteriocins: safe, natural antimicrobials for food preservation. Int Food Microbiol 71:1-20

Diep DB, Myhre R, Johnsborg O, Aakra A, Nes IF (2003) Inducible bacteriocin production in Lactobacillus is regulated by differential expression of the pln operons and by two antagonizing response regulators, the activity of which is enhanced upon phosphorylation. Mol Microbiol 47:483-494

Dobson A, Cotter P, Ross P, Hill C (2012) Bacteriocin production: a probiotic trait? Appl Environ Microbiol 78:1-6

Dunne C, Murphy L, Flynn S, O'Mahony L, O'Halloran S, Feeney M, Morrissey D, Thornton G, Fitzgerald G, Daly C, Kiely B, Quigley EMM, O'Sullivan GC, Shanahan F, Collins JK (1999) Probiotics: from myth to reality. Demonstration of functionality in animal models of disease and in human clinical trial. Antonie Van Leeuwenhoek 76:279-292

Eijsink VGH, Axelsson L, Diep DB, Havarstein LS, Holo H, Nes IF (2002) Production of class II bacteriocins by LAB; an example of biological warfare and communication. Antonie Van Leeuwenhoek 81:639-654

Ennahar S, Zendo T, Sonomoto K, Ishizaki A (1999) Investigation of bacteriocin production and purification from Nukadoko isolates displaying antimicrobial activity. Jpn J Lactic Acid Bact 10:29-36

Flynn S, van Sinderen D, Thornton GM, Holo H, Nes IF, Collins JK (2002) Characterization of the genetic locus responsible for the production of ABP-118, a novel bacteriocin produced by the probiotic bacterium Lactobacillus salivarius subsp. salivarius UCC118. Microbiology 148:973-984

Galvez A, Abriouel H, Lopez RL, Ben-omar N (2007) Bacteriocin-based strategies for food biopreservation. Int Food Microbiol 120:51-70

Guynot ME, Ramos AJ, Sanchis V, Marin S (2005) Study of benzoate, propionate, and sorbate salts as mould spoilage inhibitions on intermediate moisture bakery products of low pH (4.5-5.5). J Food Microbiol 101:161-168

Klaenhammer TR (1993) Genetics of bacteriocins produced by lactic acid bacteria. FEMS Microbiol 12:39-85

Kleerebezem M, Quadri LE (2001) Peptide pheromone-dependent regulation of antimicrobial peptide production in Gram-positive bacteria: a case of multicellular behavior. Peptides 22:1579-1596

Kruger NJ (2002) The Bradford method of protein quantification. In: Walker JW (ed) The protein protocols handbook, 2nd edn. Humana Press Inc., Totowa, pp 15-21

Leitenberger E, Rocken W (1998) HACCP in small bakeries. Food Control 9(2-3):151-155

Losteinkit C, Uchiyama K, Ochi S, Takaoka T, Nagahisa K, Shioya S (2001) Characterization of bacteriocin N15 produced by Enterococcus faecium N15 and cloning of the related genes. J Biosci Bioeng 91(4):390-395

Matsusaki H, Endo K, Sonomoto K, Ishizaki A (1996) Lantibiotic nisin Z fermentative production by Lactococcus lactis IO-1: relationship between production of lantibiotic and lactate and cell growth. Appl Microbiol Biotechnol 45:36-40

Matsusaki H, Sonomura N, Nitisinprasert S, Zendo T, Sonomoto K (2006) Biosynthesis of salivacin K21, a two- peptide bacteriocin produced by Lactobacillus salivarius AC21 isolated from the chicken intestine in Thailand, pp. 106. The 5th JSPS-NRCT joint seminar on development of thermotolerant microbial resources and their applications. November 7-10, 2006. Pattaya, Thailand 
Messaoudi S, Manai M, Kergourlay G, Prevost H, Connil N, Chobert JM, Dousset X (2013) Lactobacillus salivarius: bacteriocin and probiotic activity. Food Microbiol 36:296-304

Nes IF, Diep DB, Håvarstein LS, Brurberg MB, Eijsink V, Holo H (1996) Biosynthesis of bacteriocins in lactic acid bacteria. Antonie Van Leeuwenhoek 70:113-128

Nissen-Meyer J, Oppegrad C, Rogne P, Haugen HS, Kristiansen PE (2010) Structure and mode-of-action of the two-peptide (Class-IIb) bacteriocin. Probiotics Antimicrob Proteins 2:52-60

Ocaña V, de Ruiz Holgado AP, Nader-Macías M (1999) Characterization of a bacteriocin-like substance produced by a vaginal Lactobacillus salivarius strain. Appl Environ Microbiol 65:5631-5635

Oppegrad C, Rogne P, Emaunelsen L, Kristiansen PE, Fimland G, Nissen-Meyer J (2007) The two-peptide Class II bacteriocins: structure, production, and mode of action. J Mol Microbiol Biotechnol 13:210-219

Parente E, Ricciardi A (1999) Production, recovery and purification of bacteriocins from lactic acid bacteria. Appl Microbiol Biotechnol 52:628-638

Pilasombut K, Sakpuaram T, Wajjwalku W, Nitisinprasert S, Swetwiwathana A, Zendo T, Fujita K, Nakayama J, Sonomoto K (2006) Purification and amino acid sequence of bacteriocins produced by Lactobacillus salivarius K7 isolated from chicken intestine. Songklanakarin J Sci Technol 28:121-131

Pyler EJ (1988) Baking science and technology, 3rd edn. Sosland Publishing Company, Kansas, USA

Rollema HS, Kuipers OP, Both P, de Vos WM, Siezen RJ (1995) Improvement of solubility and stability of the antimicrobial peptide nisin by protein engineering. Appl Environ Microbiol 61:2873-2878

Rosenquist H, Hansen A (1998) The antimicrobial effect of organic acids, sour dough and nisin against Bacillus subtilis and B. licheniformis isolated from wheat bread. J Appl Microbiol 85:621-631

Sambrook JL, Fritsch EF, Maniatis T (2001) Molecular cloning: a laboratory manual, 3rd edn. Cold Spring Habor Laboratory, Cold Spring Harbor, New York

Sanger F, Coulson AR (1975) A rapid method for determining sequences in DNA by primed synthesis with DNA polymerase. J Mol Biol 94(3):441-448

Sato H, Yanagida F, Shinohara T, Yokotsuka K (2000) Restriction fragment length polymorphism analysis of 16s rRNA genes in lactic acid bacteria isolated from red wine. J Biosci Bioeng 90:335-337

Schmidt EW Jr, Gould WA, Weiser HH (1969) Chemical preservatives to inhibit the growth of Staphylococcus aureus in synthetic cream pies acidified to $\mathrm{pH} 4.5$ to 5.0. Food Technol 23:1197-1220

Siriken B, Cadirci O, Inat G, Pamuk S (2009) Microbiological examination of meatball, cream cake and Turkish Delight (Lokum). J Anim Vet Adv 8(10):2049-2054

Smith JP, Daifas DP, Ei-khoury E, Koukoutsis J, Ei-khoury A (2004) Shelf life and safety concerns of bakery product-a review. Crit Rev Food Sci Nutr 44:19-55

Stewart CM, Cole MB, Schaffner DW (2003) Managing the risk of staphylococcal food poisoning from cream-filled baked goods to meet a food safety objective. J Food Prot 66(7):1310-1325

Thompson JM, Waites WM, Dodd CER (1998) Detection of rope spoilage in bread caused by Bacillus species. J Appl Microbiol 85:481-486

Vera Pingitore E, Hebert EM, Nadar-Macias ME, Sesma F (2009) Characterization of salivaricin CRL 1328, a two-peptide bacteriocin produced by lactobacillus salivarius CRL 1328 isolated from the human vagina. Res Microbiol 160:401-408

Viedma PM, Abriouel H, Omar NB, Lopez RL, Galvez A (2009) Antistaphylococcal effect of enterocin AS-48 in bakery ingredients of vegetable origin, alone and combination with selected antimicrobials. J Food Sci 74:384-389

Viedma PM, Abriouel H, Omar NB, Lopez RL, Galvez A (2011) Inhibition of spoilage and toxigenic Bacillus species in dough from wheat flour by the cyclic peptide enterocin AS-48. Food Control 22:756-761

Wehr HM, Frank JH (2004) Standard methods for the microbiological examination of dairy products, 17th edn. APHA Inc, Washington, DC

Wongsuttichote K, Nitisinprasert S (2009) Identification of antimicrobial substance producing lactic acid bacteria isolate KUB-KJ-174 and its application as a biopreservative substance for bakery products. Kasetsart J 43:796-807

Yamamoto Y, Yoshikazu T, Shimosaka M, Okazaki M (2003) Purification and characterization of a novel bacteriocin produced by Enterococcus feacalis strain RJ-11. Appl Environ Microbiol 69:5746-5753

Zamfir M, Callewaert R, Cornea PC, De Vuyst L (2000) Production kinetics of acidophilin 801, a bacteriocin produced by Lactobacillus acidophilus IBB 801. FEMS Microbiol Lett 190:305-308

\section{Submit your manuscript to a SpringerOpen ${ }^{\circ}$ journal and benefit from:}

- Convenient online submission

Rigorous peer review

- Immediate publication on acceptance

Open access: articles freely available online

- High visibility within the field

Retaining the copyright to your article

Submit your next manuscript at $>$ springeropen.com 